\title{
The Journal of the Royal Aeronautical Society
}

WITH WHICH IS INCORPORATED THE INSTITUTION OF AERONAUTICAL ENGINEERS

\section{THE 42nd WILBUR WRIGHT MEMORIAL LECTURE}

$\mathrm{T}$ HE FORTY-SECOND Wilbur Wright Memorial Lecture, on "The Choice of Power Units for Civil Aeroplanes," was given by Dr. A. E. Russell, F.R.Ae.S., F.I.A.S., on 20th May 1954, at the Royal Institution, Albemarle Street, London, W.1.

Sir Sydney Camm, C.B.E., F.R.Ae.S., President of the Society, presided at the meeting. As has now become the custom the chief medals and prizes awarded by the Council for the year were presented before the Lecture and in addition this year, the Musick Memorial Trophy, awarded by the Royal New Zealand Aero Club to Sir Bennett Melvill Jones, was presented.

The President introduced Mr. R. M. Campbell, C.M.G., Deputy High Commissioner for New Zealand, and invited him to present the Musick Memorial Trophy.

Mr. R. M. CaMpbell, C.M.G. (Deputy High Commissioner for New Zealand): He took it that they would recall the ancestry of this trophy. Following the loss in 1938 of the Pan-American Airways aeroplane "Samoan Clipper" on its inaugural mail flight to New Zealand, when the Commander, Captain Edwin Musick, and his crew lost their lives, a fund was raised in New Zealand to purchase a trophy to perpetuate their memory. It was decided that its purpose should be to advance as far as possible the cause of safety in air travel. Everyone, whether concerned directly as a passenger himself or concerned for those who are passengers, would agree that safety was infinitely more important than speed or comfort. It was a happy thought that the memorial to Captain Musick and his crew should be expressed in an effort to improve the safety of air travel, in a tribute to those who have played a distinguished part in that cause.

This year the Royal New Zealand Aero Club decided that there was no one more deserving of the award than Sir Bennett Melvill Jones, who, over a long period, had contributed to the efficiency and safety of aircraft. They felt that he was a most worthy recipient, and in their name he had the honour to present this trophy to him.

The President then announced that this year the Council had awarded two Honorary Fellowships-the highest tribute the Society could pay. They were to Sir A. H. Roy Fedden, M.B.E., Fellow, Hon.F.I.A.S., and Air Commodore Sir Frank Whittle, K.B.E., C.B., R.A.F. (retd.), F.R.S., F.R.Ae.S. Unfortunately Sir Frank Whittle was unable to be present but he had much pleasure in presenting the scroll of Honorary Fellowship of the Society to Sir Roy Fedden, whose work was known to them all.

The President then presented the following medals :-

The Society's Gold Medal-awarded for work of an outstanding nature in Aeronautics-to

Sir GeOfFrey TaYlor, F.R.S., Hon.F.R.Ae.S., Yarrow Research Professor, for his outstanding contributions to Aeronautical Science.

The Society's Silver Medal-awarded for work of an outstanding nature in Aeronautics-to

Professor W. J. Duncan, C.B.E., D.Sc., F.R.S., F.R.Ae.S., Mechan Professor of Aeronautics and Fluid

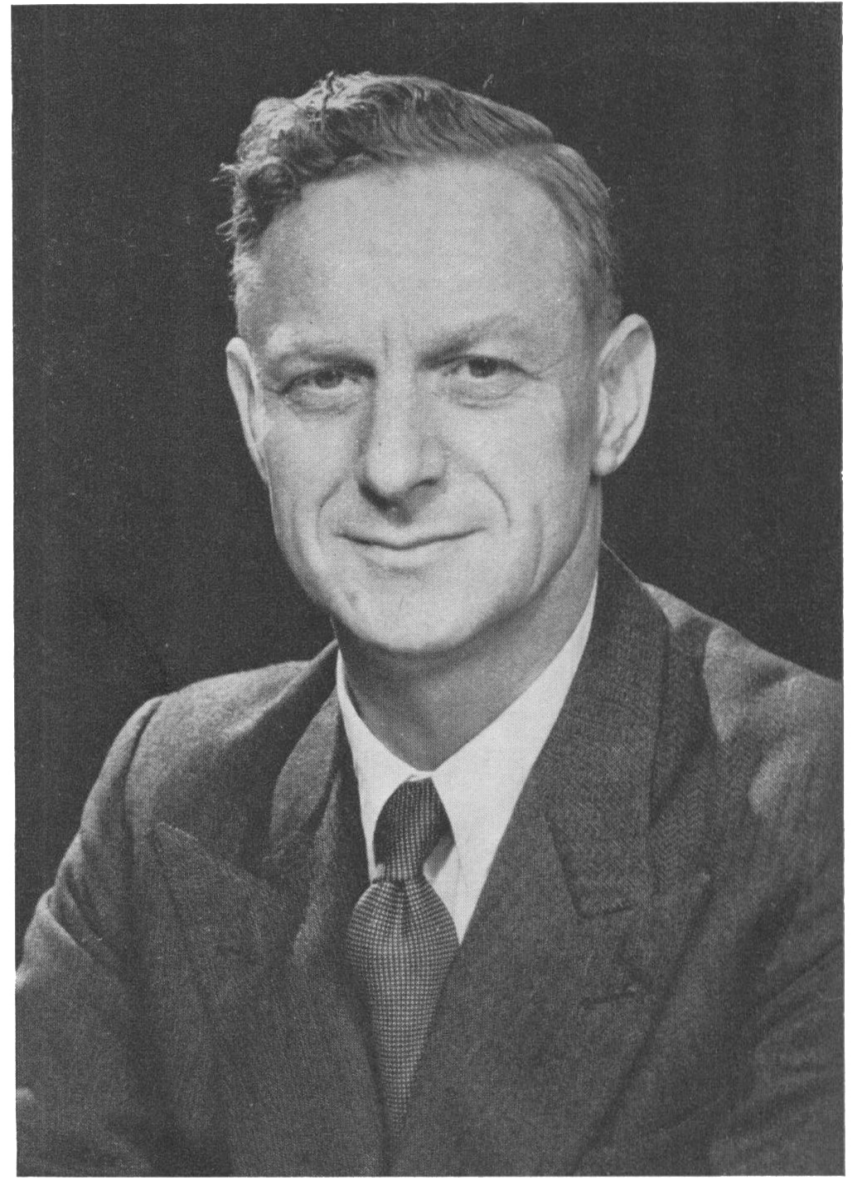

A. E. Russell, D.Sc., F.R.Ae.S., F.I.A.S., 42nd Wilbur Wright Memorial Lecturer.

Mechanics, University of Glasgow, for his outstanding work in aeronautical science and education.

The Society's Bronze Medal-awarded for work leading to an advance in Aeronautics - to

H. B. HowaRD, B.A., B.Sc., F.R.Ae.S., Assistant Director of Research, Structures, Ministry of Supply, for his long and valuable work on aircraft structures.

The British Gold Medal for Aeronautics-awarded for outstanding practical achievement leading to advancement in Aeronautics - to

A. G. ElliotT, C.B.E., F.R.Ae.S., Joint Managing Director and Chief Engineer, Rolls-Royce Ltd., for his outstanding practical achievement in the design and development of aircraft engines.

The British Silver Medal for Aeronautics - awarded for practical achievement leading to advancement in Aeronautics-to

R. A. C. Brie, A.F.R.Ae.S., Official in Charge of British European Airways Helicopter Experimental Unit, for his practical contributions to the development of rotary wing aircraft. 


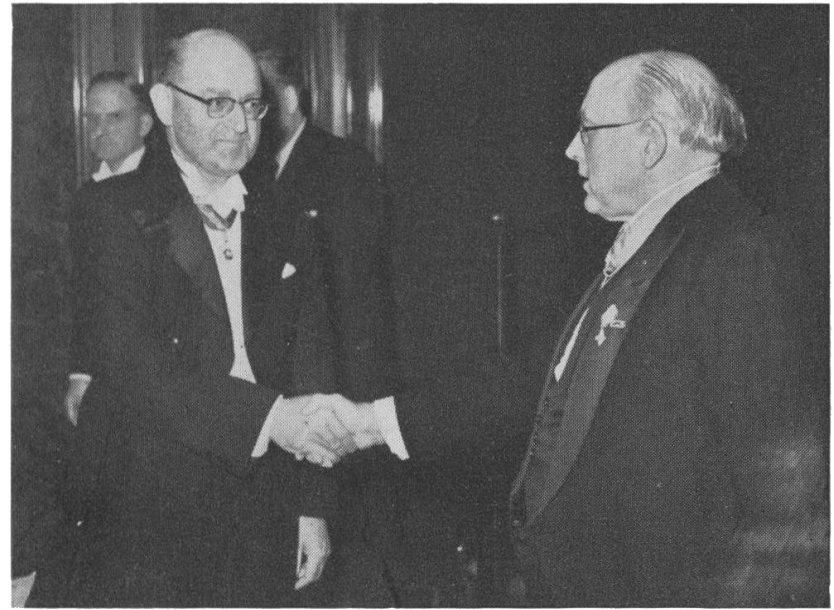

Dr. R. M. Campbell, C.M.G., Deputy High Commissioner for New Zealand, presenting the Musick Memorial Trophy to Sir BenNett Melvill Jones, C.B.E., A.F.C., M.A., F.R.S., Hon.F.I.A.S., Hon.F.R.Ae.S.

The George Taylor (of Australia) Gold Medalawarded for the most valuable contribution read before, or received by, the Society on Aircraft Design, Manufacture or Operation-to

Captain V. A. M. Hunt, B.A., A.F.R.Ae.S., Director of Control and Navigation, Ministry of Transport and Civil Aviation, for his paper on "Air Traffic Control Today and Tomorrow."

The Simms Gold Medal-awarded for the most valuable contribution read before, or received by, the Society on any subject allied to Aeronautics, such as structures, meteorology or metrology-to

E. D. KeEN, B.Sc., F.R.Ae.S., Assistant Chief Designer, Sir W. G. Armstrong Whitworth Aircraft Ltd., for his paper "Integral Construction-Its Application to Aircraft Design and its Effect on Production Methods."

The President then introduced Dr. A. E. Russell, 42nd Wilbur Wright Memorial Lecturer :

The President: I have now very great pleasure in introducing our lecturer, Dr. A. E. Russell.

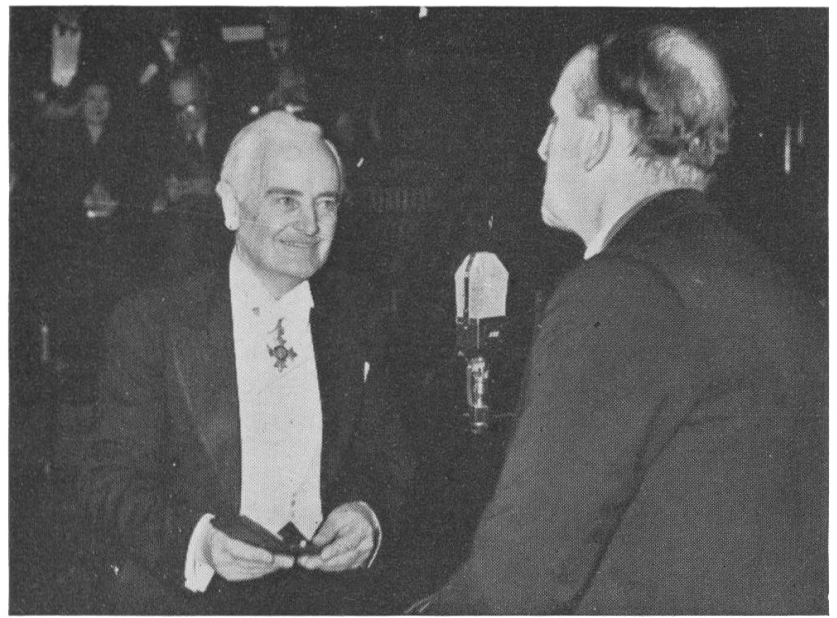

Mr. A. G. Elliotr, C.B.E., F.R.Ae.S., receiving the British Gold Medal from the President, Sir SyDNEY CAMM.

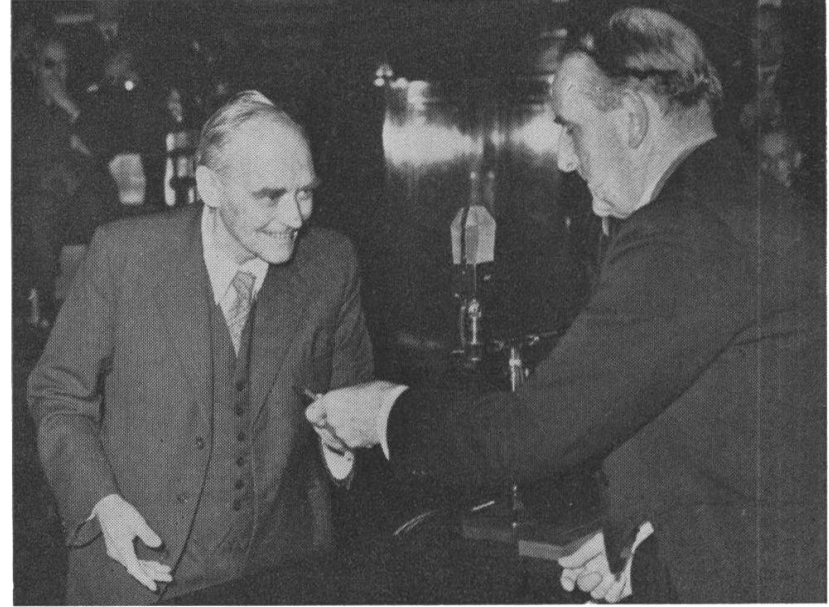

Sir Geoffrey TaYlor, F.R.S., Hon.F.R.Ae.S., receiving the Gold Medal of the Society from the President, Sir SYDNEY CAMm, C.B.E., F.R.Ae.S.

Dr. Russell was educated at Folfield Secondary School, Bristol, and at Bristol University. He joined the Bristol Aeroplane Co. Ltd. from the University in 1926, becoming Chief Technician in 1932, Deputy Chief Designer in 1937 and Chief Designer in 1943. Since 1951 he has been Director and Chief Designer, Aircraft Division. He is also a Director of Rotol Ltd.

Beginning his career in the aircraft industry under the late Captain F. S. Barnwell, who was Chief Designer of the Company from 1915 until 1936 and one of the early pioneers in aircraft development, Dr. Russell has been closely connected with and responsible for many famous Bristol aircraft; but he is probably best known as the designer of one of the biggest aeroplanes yet built-the "Brabazon"- and more recentiy as the man responsible for the "Britannia."

Dr. Russell was awarded the British Gold Medal in 1951 for practical achievement in aircraft design and was made an Honorary Doctor of Science at Bristol University in December 1951.

In December 1949 he gave the Thirteenth Wright Brothers Lecture to the Institute of the Aeronautical Sciences in Washington.

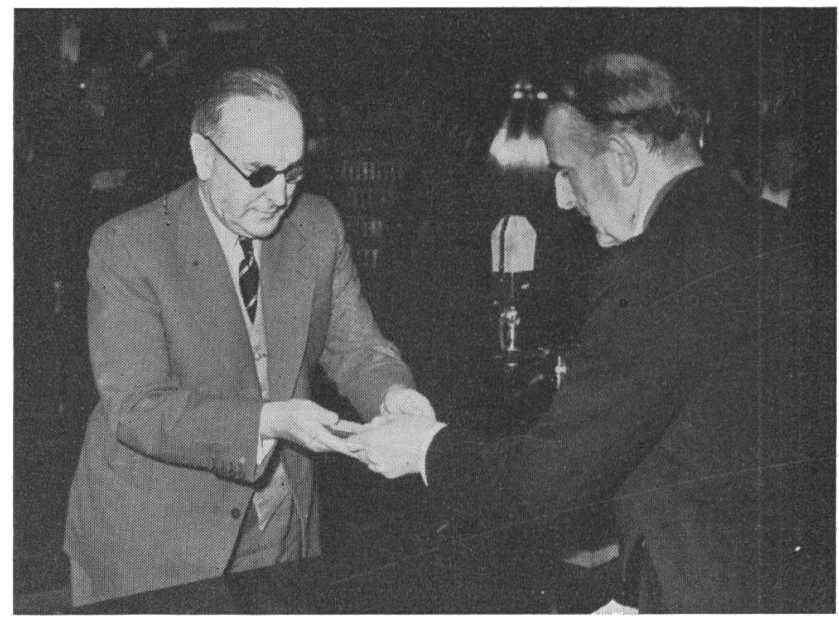

Mr. H. B. Howard, F.R.Ae.S., receiving the Bronze Medal of the Society from the President, Sir Sydney Camm. 